\title{
IDENTIFIKASI CENDAWAN PATOGEN PENYEBAB PENYAKIT PADA DAUN JABON MERAH (Anthocephalus macrophyllus (ROXB.) HAVIL)
}

\author{
Identification Fungi Pathogen Causes of Disease in Red Leaf Jabon \\ (Anthocephalus macrophyllus (Roxb.) Havil)
}

Elis Nina Herliyana ${ }^{1}$, Liza Sakbani ${ }^{1}$, Yeni Herdiyeni ${ }^{2}$, dan Abdul Munif ${ }^{3}$

(Diterima Agustus 2019/Disetujui Oktober 2020)

\begin{abstract}
Red Jabon (Anthocephalus macrophyllus (Roxb.) Havil) is a forest plant that can replace sengon (Falcataria moluccana) because it has advantages. The demand for red jabon wood is increasing, but the cultivation of red jabon is still constrained by the attack of pathogens that cause leaf disease. The attack of these pathogens can cause damage and death of seedlings so that it can be economically detrimental. The aim of this study was to identify the pathogens that cause disease in red Jabon. The method used is the Postulate Koch method, which starts from sampling red leaves with leaf disease symptoms, isolation, inoculation and analysis of disease incidence, re-isolation, and identification. Based on the identification results found as many as 2 pathogenic fungi that cause leaf spot disease, namely Pestalotia sp. and Rhizoctonia sp. In addition, 6 pathogenic fungi were found that cause blight, namely Lasiodiplodia theobromae, Fusarium sp., Colletrotrichum sp., Marssonina sp., Gloeosporium sp. 1, Gloeosporium sp. 2.
\end{abstract}

Keywords: identification, percentage of disease incidence, Postulat Koch, red jabon

\section{PENDAHULUAN}

Meningkatnya kebutuhan kayu di Indonesia tidak sejalan dengan meningkatnya produksi kayu yang berasal dari hutan alam. Berdasarkan data yang dimiliki oleh Departemen Kehutanan (2006), produksi kayu bulat dari hutan alam pada tahun 1996/1997 adalah sebesar 15 $286134 \mathrm{~m}^{3}$ dan terus mengalami penurunan hingga pada tahun 2005 hanya mampu memproduksi $5720515 \mathrm{~m}^{3}$. Menurut Mulyana dan Asmarahman (2011), produktivitas hutan alam mengalami penurunan dari tahun ke tahun akibat penebangan liar, kebakaran hutan dan berkurangnya luas kawasan hutan karena konversi lahan hutan menjadi areal pemukiman, perkebunan dan pertanian. Mengingat hal tersebut tentu harus ada jalan keluarnya. Apabila kondisi ini dibiarkan, Indonesia akan kekuarangan stok kayu untuk konsumsi di dalam negeri.

Pemerintah melalui KLHK saat ini memacu pembangunan hutan tanaman, hutan kemasyarakatan (Hutan Tanaman Rakyat/HTR) dan hutan rakyat. Mulyana dan Asmarahman (2011) menyatakan bahwa tingginya kebutuhan bahan baku industri perkayuan nasional merupakan salah satu alasan untuk membudidayakan tanaman hutan. Salah satu tanaman

\footnotetext{
${ }^{1}$ Departemen Silvikultur, Fakultas Kehutanan

Institut Pertanian Bogor

* Penulis korespondensi:

e-mail: elisherliana@yahoo.com

${ }^{2}$ Departemen Ilmu Komputer, FMIPA, Institut Pertanian Bogor

${ }^{3}$ Departemen Proteksi Tanaman, Fakultas Pertanian, Institut Pertanian Bogor
}

kehutanan yang memiliki prospek yang baik saat ini secara ekonomi adalah tanaman sengon (Falcataria moluccana). Namun, tanaman sengon saat ini masih banyak terserang hama dan penyakit. Sebagai pengganti sengon, tanaman kehutanan yang memiliki potensi kayu yang baik adalah Jabon (Anthocephallus sp.).

Halawane (2011) menyatakan bahwa Jabon saat ini mulai menjadi andalan industri perkayuan, termasuk kayu lapis, kayu lamina dan industri perkayuan lainnya. Pasalnya, jabon memiliki beberapa keunggulan dibandingkan dengan tanaman kayu lainnya seperti sengon, akasia, pinus dan ekaliptus yang sudah populer sebelumnya. Selain pertumbuhannya yang cepat, keunggulan jabon diantaranya memiliki tingkat kelurusan batang yang baik, rantingnya dapat rontok dengan sendiri (self pruning) sehingga tidak memerlukan pemangkasan.

Indonesia memiliki dua jenis jabon komersial yaitu jabon putih (Anthocephalus cadamba Roxb.) dan jabon merah (Anthocephalus macrophyllus (Roxb.). Jabon merah ternyata lebih banyak diminati dibandingkan jabon putih karena kualitas kayu jabon merah yang lebih unggul.

Saat ini dibutuhkan pasokan bibit jabon dalam jumlah yang besar, namun pengembangan bibit jabon merah mengalami kendala berupa serangan patogen penyebab penyakit daun di persemaian. Gejala penyakit yang biasanya terdapat pada tanaman jabon adalah bercak daun dan hawar daun. Sehingga perlu dilakukan identifikasi cendawan penyebab penyakit daun sehingga dapat diketahui tindakan penanggulangan yang tepat. 
Postulat Koch merupakan suatu metode yang digunakan untuk mengetahui hubungan sebab akibat antara patogen dengan gejala penyakit. Rangakaian Postulat Koch terdiri dari isolasi, inokulasi, reisolasi, dan identifikasi patogen yang menyerang suatu organisme. Menurut Aisah (2014), Postulat Koch digunakan untuk membuktikan isolat yang diperoleh merupakan agen penyebab dari gejala penyakit yang diamati. Postulat Koch juga digunakan sebagai metode untuk mengidentifikasi cendawan penyebab gejala penyakit daun pada jabon merah. Tujuan penelitian ini adalah mengidentifikasi cendawan penyebab penyakit daun pada jabon merah menggunakan uji Postulat Koch.

\section{METODE PENELITIAN}

\section{Waktu Dan Tempat Penelitian}

Penelitian ini dilaksanakan pada bulan Maret - April 2017 di Laboratorium Patologi Hutan Departemen Silvikultur Fakultas Kehutanan IPB

\section{Alat dan Bahan}

Alat yang digunakan dalam penelitian ini yaitu cawan Petri, sudip, pembakar bunsen, mikroskop, optilab, laminar airflow, autoklaf, aluminium foil, object glass, plastic wrap, labu erlenmeyer, sprayer, oven, botol selai, gunting, kapas dan plastik ukuran $2 \mathrm{~kg}$. Bahan yang digunakan yaitu alkohol, akuades, daun jabon yang telah terinfeksi cendawan penyebab penyakit hawar daun dan bercak daun, media PDA steril, serta bibit jabon merah berumur 2 bulan.

\section{Prosedur Pengujian Postulat Koch}

Uji Postulat Koch dimulai dari isolasi, inokulasi, reisolasi, hingga identifikasi. Berikut adalah metode pengujian Postulat Koch yang dilakukan:.

\section{Isolasi}

Jabon merah yang bergejala penyakit hawar daun dan bercak daun diisolasi dengan cara mengambil daun yang telah terinfeksi, kemudian dipotong antara bagian jaringan yang terinfeksi dengan jaringan yang belum terinfeksi. Bagian tersebut kemudian direndam dengan alkohol 70\% dan dicuci dengan air steril sebanyak 3 kali pencucian. Setelah itu, bagian tersebut diletakan pada kertas saring di atas cawan Petri. Kemudian diletakan pada cawan Petri steril yang berisi PDA steril. Semua kegiatan isolasi dilakukan di dalam laminar air flow untuk menjaga sterilisasi isolat. Isolasi dilakukan untuk mengamati pertumbuhan cendawan yang diinkubasi selama dua minggu kemudian dilakukan pemurnian dan perbanyakan.

\section{Inokulasi dan Kejadian Penyakit}

Isolat-isolat yang diperoleh kemudian diinokulasi pada bibit jabon merah berumur 2 bulan yang sehat dan berasal dari Bogor. Perbedaan asal tanaman ini dimaksudkan untuk mengetahui apakah ada pengaruh cendawan dari Halmahera terhadap bibit jabon merah dari Bogor. Menurut Ismail et al. (2012), teknik inokulasi yaitu penempelan blok agar pada tanaman jabon merah. Inokulasi dilakukan dengan 2 perlakuan pada setiap bibit yaitu daun yang dilukai dan yang tidak dilukai. Ulangan dibuat sebanyak 3 kali pengulangan dari setiap isolat yang diperoleh. Pelukaan pada daun untuk setiap isolat dilakukan dengan menggunakan jarum suntik yang steril. Bibit yang telah diinokulasi kemudian ditutup menggunakan plastik. Hal ini bertujuan untuk menghindari penguapan yang berlebihan serta menjaga kelembaban bibit. Pengamatan dilakukan selama 7 hari untuk mengetahui gejala yang timbul pada tanaman jabon merah.

Kejadian penyakit pada bibit jabon merah yang didapatkan setelah inokulasi kemudian dihitung menggunakan rumus sebagai berikut (Achmad et al. 2012):

$$
K j P=\frac{n}{N} x 100 \%
$$

Keterangan:

$$
\begin{array}{ll}
\mathrm{KjP} & =\text { Kejadian Penyakit } \\
\mathrm{n} & =\text { Jumlah bibit yang terserang } \\
\mathrm{N} & =\text { Jumlah bibit yang diamati }
\end{array}
$$

Keparahan penyakit diukur menggunakan rumus sebagai berikut (Stević et al. 2010):

$$
K p P=\sum \frac{n V}{Z N} x 100 \%
$$

Keterangan:

$\mathrm{KpP}=$ Keparahan Penyakit

$\mathrm{n} \quad=$ Jumlah tanaman dalam setiap kategori

$\mathrm{V} \quad=$ Nilai numerik dari kategori serangan

$\mathrm{Z}=$ Kategori serangan dengan nilai numerik tertinggi

$\mathrm{N}=$ Jumlah seluruh tanaman yang diamati

Nilai numerik kategori serangan dan keparahan penyakit disajikan pada Tabel 1.

\section{Reisolasi}

Reisolasi dilakukan apabila telah muncul gejala pada jabon merah. Patogen penyebab penyakit pada jabon merah merupakan patogen yang sama apabila gejala hasil inokulasi patogen tersebut identik dengan gejala sebelum

Tabel 1 Nilai numerik kategori serangan dan keparahan penyakit bercak daun dan hawar daun pada bibit jabon merah

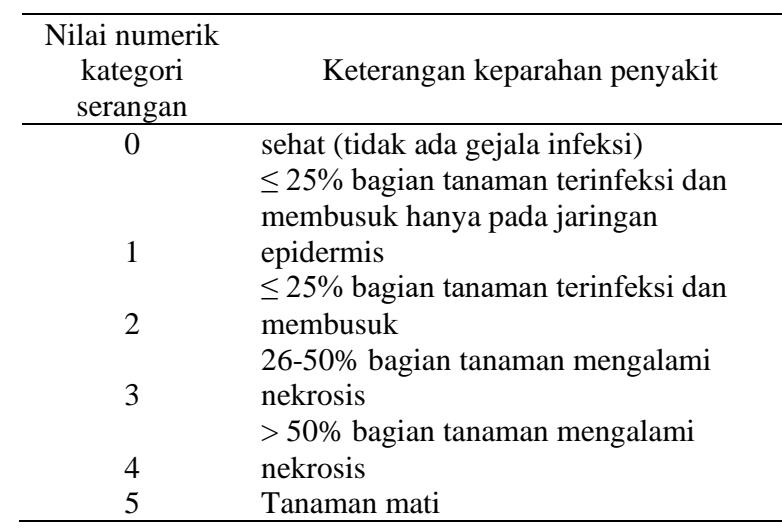

Sumber: Stević et al. (2010) dengan modifikasi 
isolasi. Metode kerja pada kegiatan reisolasi sama dengan kegiatan isolasi.

\section{Identifikasi}

Identifikasi cendawan dilakukan dengan menggunakan mikroskop yang terhubung optilab untuk melihat ciri khusus dan menentukan jenis cendawan yang tumbuh dari kegiatan isolasi yang dilakukan. Cara identifikasi dengan cara mencocokan ciri khusus patogen menggunakan buku identifikasi oleh Barnet (1965) dan menanyakan pada ahli. Identifikasi juga dapat dilakukan dengan melihat ciri morfologi menggunakan Support Vector Machine (SVM) (Manik et al. 2016).

\section{HASIL DAN PEMBAHASAN}

\section{Gejala Penyakit}

Kejadian penyakit didasari oleh adanya inang dan patogen. Hubungan antara inang dan patogen dapat dilihat dari tanda dan gejala yang muncul. Kejadian infeksi penyakit dapat diketahui dari sejak munculnya gejala. Kejadian utama dalam siklus penyakit dimulai dari inokulasi, penetrasi, infeksi, penyebaran, kolonisasi, pemencaran, dan daya bertahan hidup patogen tanpa inang (Agrios 2005). Menurut Herliyana et al (2012) dan Aisah (2014), penyakit bercak daun disebabkan oleh fungi Rhizoctonia sp. Gejala bercak daun umumnya sama pada setiap tanaman, yaitu berupa luka atau noda yang bersifat lokal pada daun inang yang menyebabkan sel-sel mati (nekrosis) pada daun (Agrios 2005).

Bercak daun memiliki ciri yaitu terjadi nekrosis berupa bercak pada daun dengan warna kecoklatan dan membulat tidak beraturan, dapat terlepas sehingga daun berlubang (Gambar 1.a). Hal ini sesuai dengan tulisan
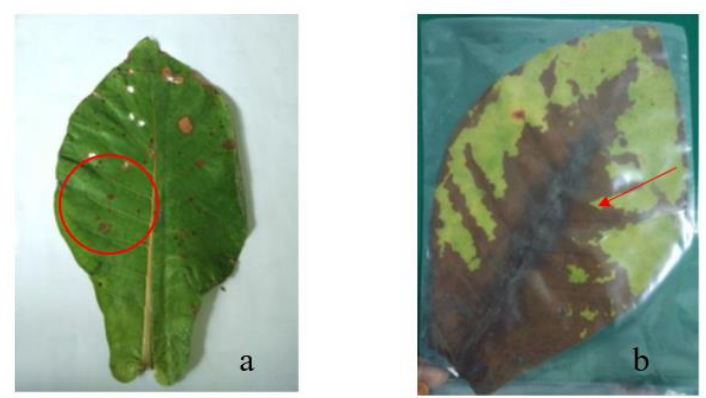

Gambar 1 (a) Gejala bercak daun pada daun jabon merah (b) Gejala hawar daun pada daun jabon merah (Skala 1:3)
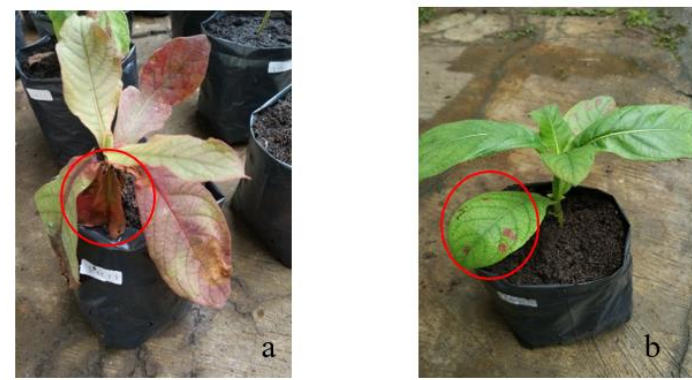

Gambar 1 (a) Bibit yang terserang hawar daun, (b) Bibit yang terserang bercak daun (Skala 1:10)
Manik et al. (2016) yang menyebutkan bahwa adanya bercak-bercak pada daun yang merupakan kematian jaringan yang berwarna kuning hingga kecoklatan merupakan tanda dan gejala awal dari penyakit bercak daun. Bentuk nekrosis pada daun berbentuk bulat, lonjong, dan tidak beraturan.

Gejala hawar daun memiliki ciri-ciri daun dengan nekrosis yang menyebar, tidak beraturan, berwana coklat, dan mengering seperti pada (Gambar 1.b). Gejala hawar daun lebih cepat menyebar dibandingkan dengan gejala bercak daun. Menurut Rahayu (1999), apabila terjadi kematian seluruh atau sebagian anggota tumbuhan secara cepat, maka penyakit tersebut adalah penyakit hawar.

\section{Persentase Serangan, Kejadian Penyakit dan Keparahan Penyakit}

Hasil dari inokulasi cendawan penyebab bercak daun dan hawar daun menunjukkan bahwa hampir seluruh inokulum menimbulkan gejala pada bibit jabon merah terutama pada daun yang dilukai. Berikut persentase serangan penyakit setelah inokulasi selama 1 minggu dapat dilihat pada Gambar 3.

Isolat pada perlakuan S17 1 menunjukkan persentase kejadian penyakit tertinggi pada baik pada daun yang dilukai maupun tidak dilukai. Isolat tersebut didapatkan dari daun yang bergejala hawar daun. Rata-tata persentase serangan penyakit pada daun yang dilukai sebesar $10.03 \%$ dan pada daun yang tidak dilukai sebesar $4.8 \%$ ). Terlihat bahwa persentase serangan tertinggi terdapat pada daun yang dilukai. Menurut Yunasfi (2002), gejala dan tanda yang terjadi pada tanaman yang terserang penyakit hawar adalah organ daun, cabang, batang, dan bunga menjadi coklat dengan sangat cepat dan menyeluruh yang akan menyebabkan kematian. Sehingga penyakit hawar daun memiliki persentase kejadian penyakit yang lebih besar.

Setelah inokulasi, maka diperoleh perhitungan kejadian penyakit $(\mathrm{KjP})$ dan keparahan penyakit $(\mathrm{KpP})$ yang dapat dilihat pada Tabel 3. Persentase kejadian penyakit merupakan persentase banyaknya tanaman yang terserang dari total seluruh tanaman yang diamati. Sedangkan persentase keparahan penyakit merupakan persentase luasan jaringan tanaman yang terserang patogen dari total luasan yang ada. Pada Tabel 3 dapat dilihat bahwa persentase kejadian penyakit yang tertinggi sebanyak $66.67 \%$ terdapat pada bibit yang diinokulasi dengan cara dilukai. Sementara, persentase keparahan

Tabel 3 Hasil perhitungan rata-rata persentase serangan, kejadian penyakit $(\mathrm{KjP})$ dan keparahan penyakit $(\mathrm{KpP})$ setelah inokulasi

\begin{tabular}{ll}
\hline Rata-rata Persentase Serangan, KjP dan KpP & Persentase \\
\hline $\begin{array}{l}\text { Rata-rata Persentase Serangan } \\
\text { (daun dilukai) }\end{array}$ & 10.03 \\
$\begin{array}{l}\text { Rata-rata Persentase Serangan } \\
\text { (daun tidak dilukai) }\end{array}$ & 4.8 \\
KjP(daun dilukai) & 66.67 \\
$\mathrm{KjP}($ daun tidak dilukai) & 24.24 \\
$\mathrm{KpP}($ daun dilukai) & 3.27 \\
$\mathrm{KpP}$ (daun tidak dilukai) & 9.16 \\
\hline
\end{tabular}


penyakit yang tertinggi terdapat pada bibit yang diinokulasi tanpa pelukaan yaitu sebesar $9.16 \%$.

\section{Identifikasi}

Hasil identifikasi penelitian ini ditemukan sebanyak 2 cendawan patogen penyebab penyakit bercak daun yaitu Pestalotia sp. dengan kode isolat $\mathrm{AC}$ dan Rhizoctonia sp. dengan kode isolat $\mathrm{AD}$, dan 6 cendawan patogen penyebab penyakit hawar daun yaitu Lasiodiplodia theobromae dengan kode isolat S16 1, Fusarium sp. dengan kode isolat S11 1, Colletrotrichum sp. dengan kode isolat S11 2, Marssonia sp. dengan kode isolat S10 1, Gloeosporium sp. 1 dengan kode isolat S17 1, Gloeosporium sp. 2 dengan kode isolat S17 2.

\section{Cendawan Penyebab Gejala Bercak Daun}

\section{Pestalotia sp.}

Hasil identifikasi diperoleh Pestalotia sp. dengan kode isolat AC merupakan patogen dari daun bergejala penyakit bercak daun. Pestalotia juga merupakan cendawan penyebab penyakit bercak merah (Hidayah dan Anggraeni 2015). Hasil inokulasi menunjukkan Pestalotia sp. menghasilkan pesentase serangan sebanyak $30 \%$ pada daun jabon merah yang dilukai dan sebanyak $20 \%$ pada daun jabon merah yang tidak dilukai.

Faktor yang mempengaruhi perkembangan Pestalotia sp. adalah suhu dan kelembaban tanah. Utami et al. (2008) menjelaskan dalam penelitiannya bahwa patogen Pestalotia sp. juga dapat menyerang bibit jelutung (Dyera spp.). Gejala bercak daun pada jabon merah yang disebabkan oleh Pestalotia sp. yaitu nekrosis berupa bercak pada daun berwarna coklat, kering berbentuk lingkaran tidak beraturan yang dapat terlepas sehingga daun berlubang-lubang (Gambar 4 (a)). Warna dan ciri isolat dari Pestalotia sp. adalah putih bersih, kemudian menjadi Off White, permukaan seperti kapas, dan terlihat garis pertumbuhan seperti lingkaran tidak beraturan. (Gambar 4 (b)). Pertumbuhan hifanya hingga sampai cawan Petri penuh $(\varnothing=9 \mathrm{~cm})$ dari hasil pengamatan yaitu selama 9 hingga 10 hari. Hifanya bersepta, hialin, mempunyai tubuh buah yang disebut aservuli yang terletak di bawah epidermis tanaman inang (Utami et al. 2008). Konidia cendawan ini berbentuk lonjong bersekat-sekat dan mempunyai ekor seperti benang sebanyak 2 hingga 3 . Hal tersebut sesuai dengan
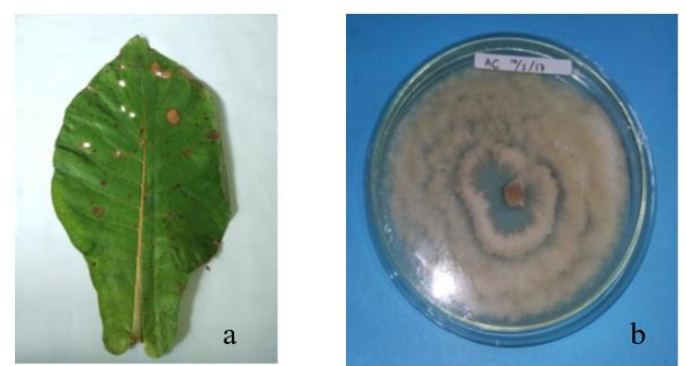

Gambar 4 (a) Gejala Bercak daun dari Pestalotia sp (Skala 1:10), (b) Isolat Pestalotia sp. (Skala 1:3)
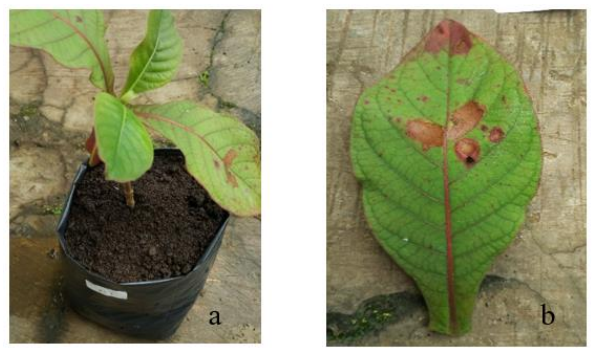

Gambar 5 (a) Bibit yang terserang Pestalotia sp. (Skala 1:10), (b) Gejala akibat cendawan Pestalotia sp. (Skala 1:3)
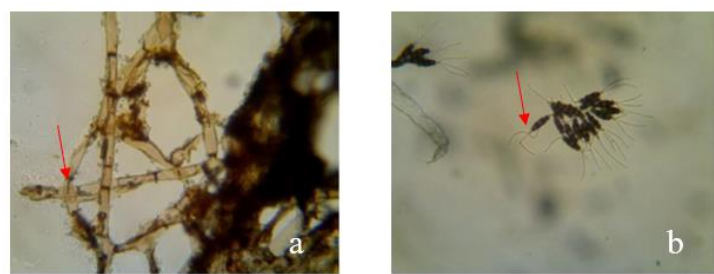

Gambar 6 (a) Hifa dari Pestalotia sp. di bawah mikroskop dengan pembesaran 400x (b) Konidia Pestalotia sp. di bawah mikroskop dengan pembesaran $400 \mathrm{x}$

\section{Persentase Serangan Penyakit Setelah Inokulasi}

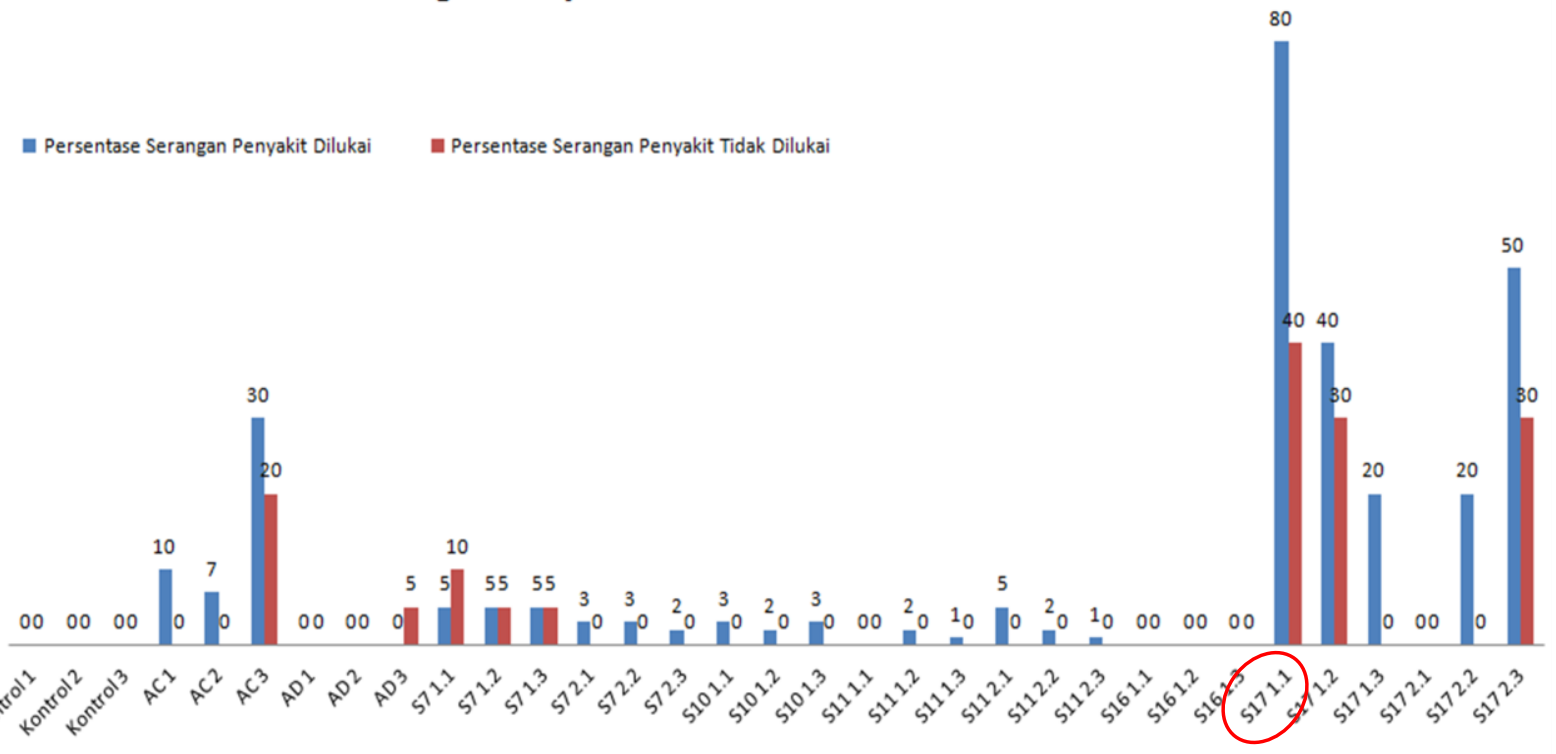

Gambar 2 Grafik Persentase Serangan Penyakit Setelah Inokulasi 
sifat-sifat fungi Pestalotia yang dikemukakan oleh Barnet (1965) dan Yamni et al. (2006). Adapun bentuk hifa dan konidia dari Pestalotia sp. Dapat dilihat pada Gambar 6.

Suhu optimum cendawan berkisar $25^{\circ} \mathrm{C}-30^{\circ} \mathrm{C}$ dan kelembabannya sekitar $90 \%$. Tindakan pencegahan terhadap serangan patogen Pestalotia sp. sebaiknya dilakukan sejak dini. Teknik pengendalian patogen Pestalotia sp. yang umum dilakukan menurut Rahayu (1999) yaitu, sanitasi area pertanaman, mencabut dan membakar tanaman yang sakit, dan bila perlu dilakukan penyemprotan fungisida.

\section{Rhizoctonia sp.}

Persentase serangan patogen dari hasil inokulasi menunjukkan bahwa Rhizoctonia sp. menghasilkan pesentase serangan yaitu $5 \%$ pada daun jabon merah yang tidak dilukai. Hasil tersebut merupakan hasil yang tertinggi dari 3 ulangan bibit jabon merah yang diinokulasi patogen Pestalotia sp. Hal ini sesuai dengan Herliyana et al. (2012) dan Aisah (2014) penyakit bercak daun disebabkan oleh fungi Rhizoctonia sp.
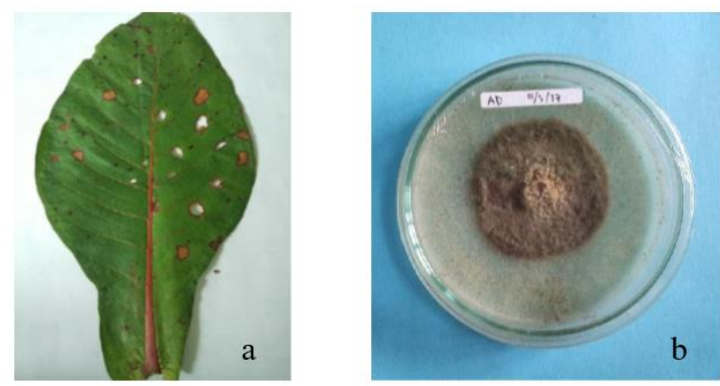

Gambar 7 (a) Gejala bercak daun dari Rhizoctonia sp. (Skala 1:10), (b) Isolat Rhizoctonia sp. (Skala $1: 3)$
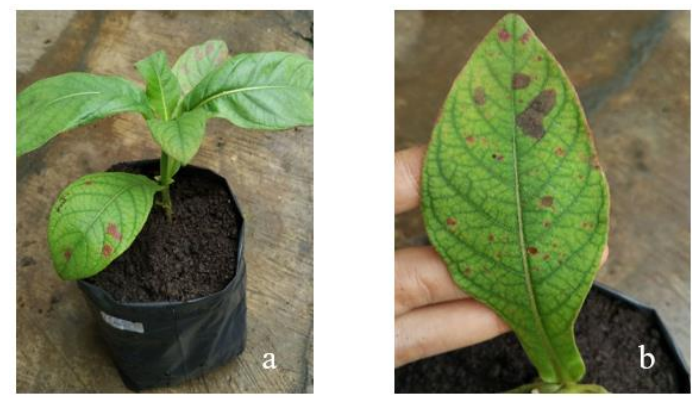

Gambar 8 (a) Bibit yang terserang Rhizoctonia sp. (Skala 1:10), (b) Gejala akibat cendawan Rhizoctonia sp. (Skala 1:3)

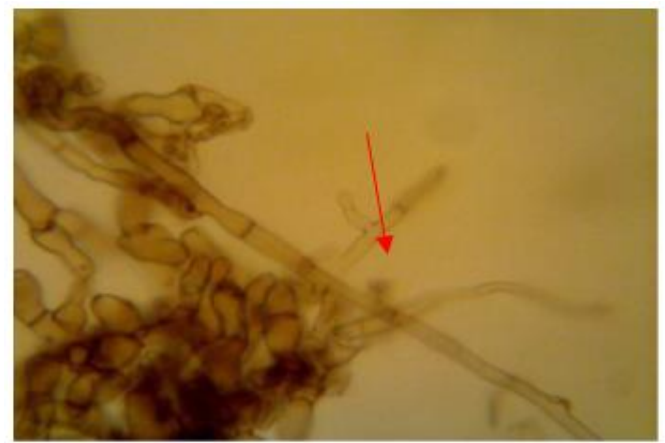

Gambar 9 Misella Rhizoctonia sp. di bawah mikroskop dengan pembesaran $400 \mathrm{x}$
Menurut Soenartiningsih et al. (2015) dan Walker (1975), cendawan Rhizoctonia sp. merupakan cendawan yang dapat menular melalui tanah dan benih. Suhu optimum cendawan berkisar $25^{\circ} \mathrm{C}-30^{\circ} \mathrm{C}$ dan kelembabannya sekitar 90\%. Gejala dari patogen Rhizoctonia sp. mirip dengan gejala pada Pestalotia sp. dapat dilihat pada Gambar 7 (a). Hal tersebut disebabkan karena kedua patogen tersebut merupakan penyebab penyakit bercak daun. Warna dan ciri isolat dari patogen Rhizoctonia sp. pada masa awal pertumbuhan berwarna putih, kemudian menjadi putih ke coklat pada isolat yang penuh dan warnanya lebih gelap di tengah, miselium menyebar tipis di permukaan cawan. Gambar 7 (b) merupakan isolat dari Rhizoctonia sp. yang telah berwarna kecoklatan dan berwarna lebih gelap di tengah isolat.

Sklerotium pada Rhizoctonia sp. berbentuk sudut siku-siku dipercabangannya dan bersekat (Gambar 9), tidak membentuk konidia, serta memiliki panjang hifa 8$12 \mu \mathrm{m}$ (Agrios 2005). Pencegahan dan pengendalian Rhizoctonia sp. dapat dilakukan dengan cara menyemprotkan pestisida sintetik, menggunakan varietas tahan, pengendalian secara mekanis dan fisis seperti membakar tanaman yang terinfeksi juga dilakukan dengan pengendalian hayati menggunakan agen hayati seperti Tricoderma sp. (Soenartiningsih 2015).

\section{Cendawan Penyebab Gejala Hawar Daun}

\section{Marssonina sp.}

Isolat dengan kode S10 1 merupakan hasil isolasi daun yang bergejala penyakit hawar daun. Ciri-ciri dari isolat ini memiliki warna hitam dan sedikit kecoklatan, miselium mengembang ke atas permukaan cawan. Hasil dari inokulasi, patogen pada isolat ini menyerang daun jabon merah dengan persentase serangan sebesar $2 \%$ dari total permukaan daun yang dilukai dan tidak menyebabkan nekrosis pada daun yang tidak dilukai.

Identifikasi mikroskopis menggunakan mikroskop yang terhubung dengan optilab menunjukkan ciri-ciri dari patogen S10 1, yaitu memiliki konidia yang transparan (hialin) berbentuk seperti dua sel yang akan membelah (seperti angka delapan) dan memiliki hifa yang bersekat diduga adalah Marssonina sp.. Menurut Lee et al (2011), koloni isolat berwarna coklat sampai kehitaman, sedangkan konidia hialin dan berbentuk sedikit melengkung (obovoid), terbentuk dari dua sel yang berukuran berbeda merupakan ciri dari Marssonina sp.

Suhu optimum cendawan berkisar $25^{\circ} \mathrm{C}-30^{\circ} \mathrm{C}$ dan kelembabannya sekitar $90 \%$. Pencegahan dan
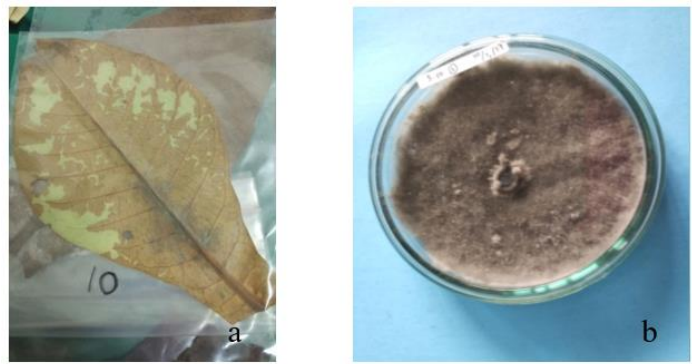

Gambar 10 (a) Gejala hawar daun dari Marssonina sp. (Skala 1:0), (b) Isolat Marssonina sp. (Skala 1:3) 
pengendalian dilakukan dengan menanam tanaman yang resisten, sanitasi, dan pemusnahan tanaman yang telah terinfeksi.

\section{Fusarium sp.}

Isolat S11 1 merupakan isolat patogen dari daun jabon merah yang bergejala hawar daun. Warna dan ciri dari isolat ini yaitu berwarna abu-abu, sedikit putih, dan miselium tumbuh melingkar-lingkar pada permukaan cawan. Persentase serangan patogen setelah inokulasi sebesar 2\% dari keseluruhan luas permukaan daun jabon merah yang dilukai dan tidak menimbulkan nekrosis pada daun yang tidak dilukai.

Hasil identifikasi melalui mikroskop, isolat patogen ini memiliki ciri-ciri mikroskopis konidia seperti bulan sabit dan miselium bersekat. Ciri-ciri tersebut diduga merupakan ciri-ciri dari Fusarium sp. Menurut Semangun (1996), mikrokonidia dari Fusarium sp. bersel satu atau dua, hialin, berukuran 5-7 x 2.5-3 $\mu \mathrm{m}$, sedangkan makrokonidia bebentuk sabit, bertangkai kecil, dan kebanyakan bersel 4.

Fusarium sp. juga menyebabkan penyakit mati pucuk pada tanaman jabon menurut Aisah (2014). Penyebaran patogen ini dapat melalui kontak langsung sesama inang, angin, air, dan tanah yang telah terinfeksi. Menurut Rahayu et al. (2015), suhu dan kelembaban optimum Fusarium sp. adalah sebesar $30^{\circ} \mathrm{C}$ dan $90 \%$. Pencegahan dan pengendaliannya yaitu dengan menggunakan biopestisida, musuh alami, dan pemusnahan inang yang terinfeksi.

\section{Colletrotrichum sp.}

Colletrotrichum sp. merupakan hasil identifikasi dari kode isolat S11 2. Gejala dari patogen ini adalah
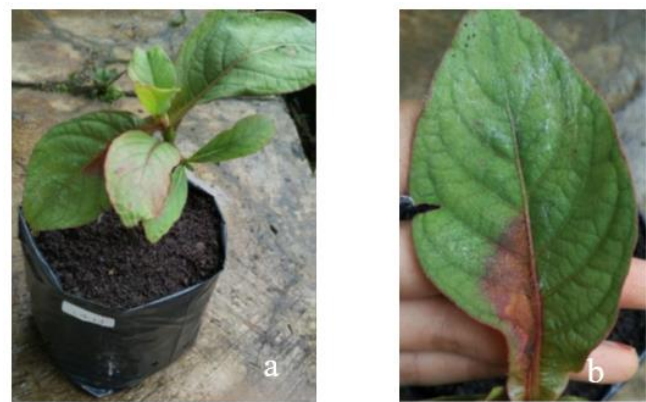

Gambar 11 (a) Bibit yang terserang Marssonina sp. (Skala 1:10), (b) Gejala akibat cendawan Marssonina sp. (Skala 1:3)

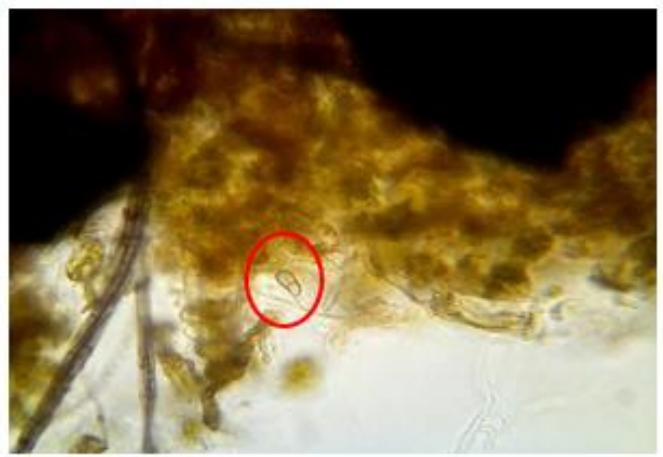

Gambar 12 Konidia Marssonina sp. di bawah mikroskop dengan perbesaran $400 \mathrm{x}$ hawar daun, dapat dilihat pada Gambar 16 (a). Irawan et al. (2015) menyatakan bahwa Colletrotrichum sp. dapat menyerang tanaman cempaka (Magnolia elegans (Blume.) H. Keng) dengan gejala penyakit bercak daun dan antraknosa. Hal ini menunjukkan bahwa gejala yang muncul berbeda pada setiap jenis tanaman maupun jenis patogennya. Warna dari isolat Colletrotrichum sp. yaitu abu-abu kehitaman membentuk lingkaran tidak beraturan (Gambar 16 (b). Colletrotrichum sp. adalah cendawan yang termasuk dalam kelas Deuteromycetes, Ordo Melanconiales, dan Famili Melanconiaceae (Agrios 2005).

Spora Colletrotrichum sp. dapat disebarkan lewat air hujan dan apabila menempel pada inang yang cocok maka akan berkembang dengan cepat (Kronstad 2000). Ciri-ciri umum dari Colletrotrichum sp. adalah memiliki hifa yang bersekat dan memiliki konidia yang transparan dan memanjang dengan ujung yang membulat atau meruncing dengan panjang 10-16 $\mu \mathrm{m}$ dan lebarnya sekitar 5-7 $\mu \mathrm{m}$. Konidia berwarna hitam (Gambar 18), sedangkan hifanya berwarna abu-abu (Hyde et al. 2009).

Suhu optimum cendawan berkisar $25^{\circ} \mathrm{C}-30^{\circ} \mathrm{C}$ dan kelembabannya sekitar $90 \%$. Pencegahan dan
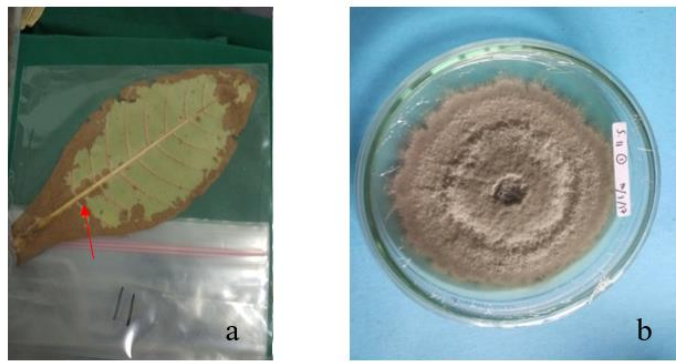

Gambar 13 (a) Gejala hawar daun dari Fusarium sp. (Skala 1:10), (b) Isolat dengan Fusarium sp. (Skala 1:3)
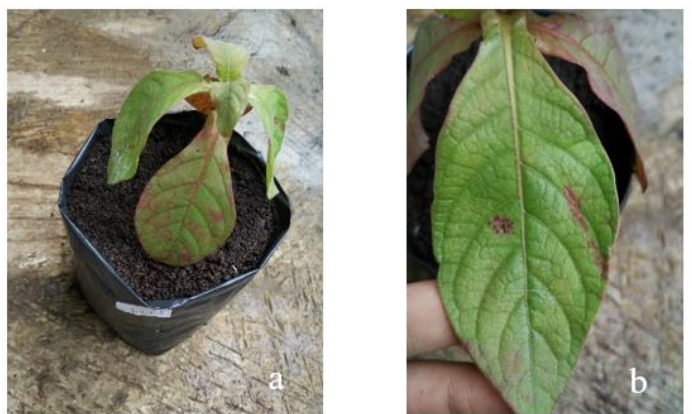

Gambar 14 (a) Bibit yang terserang Fusarium sp. (Skala 1:3), (b) Gejala akibat cendawan Fusarium sp. (Skala 1:3)

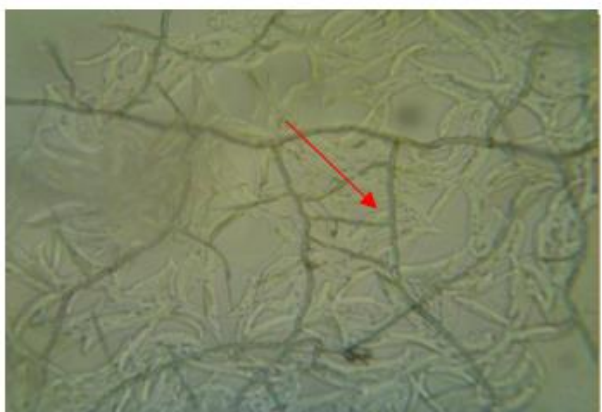

Gambar 15 Konidia Fusarium sp. Dibawah mikroskop dengan perbesaran $400 x$ 
pengendalian untuk patogen Colletrotrichum sp. ini sama seperti patogen-patogen sebelumnya. Menurut Hidayah dan Anggraeni (2015), Colletrotrichum sp. ini merupakan patogen yang dapat bertahan hidup tanpa adanya tanaman inang, yaitu hidup secara saprofit pada jaringan mati dengan membentuk struktur istirahat.

\section{Lasiodiplodia theobromae}

Lasiodiplodia theobromae merupakan salah satu patogen penyebab penyakit mati pucuk pada bibit jabon menurut Aisyah (2014). Isolat dengan kode S16 1 ini didapatkan dari daun yang bergejala hawar daun. Warna dan ciri isolate yaitu hitam keabu-abuan dan permukaan miselium seperti kapas.

Setelah inokulasi pada daun jabon merah yang dilukai maupun tidak dilukai, tidak menimbulkan gejala (nekrosis) selama masa pengamatan 7 hari, namun mengalami gejala hawar daun setelah masa pengamatan. Warna isolat ini yaitu hitam keabu-abuan dan menggumpal ditengah.
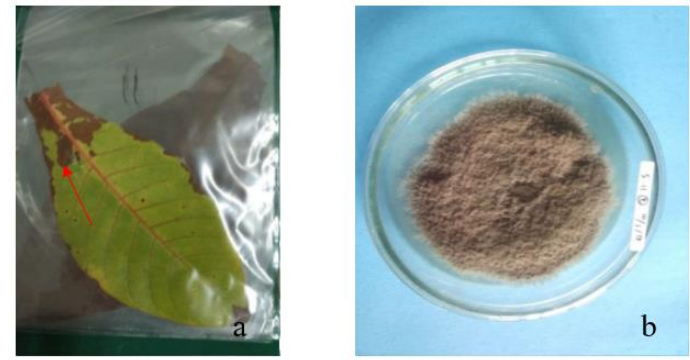

Gambar 16 (a) Gejala hawar daun dari Colletrotrichum sp. (Skala 1:10), (b) Isolat Colletrotrichum sp. (Skala 1:5)
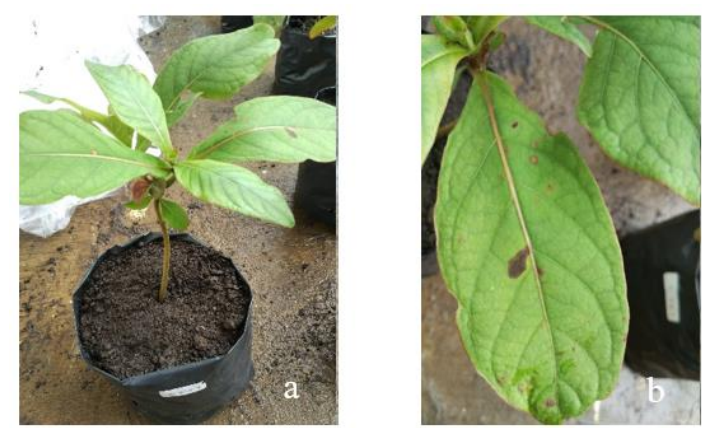

Gambar 17 (a) Bibit yang terserang Colletrotrichum sp., (b) Gejala akibat cendawan Colletrotrichum sp.

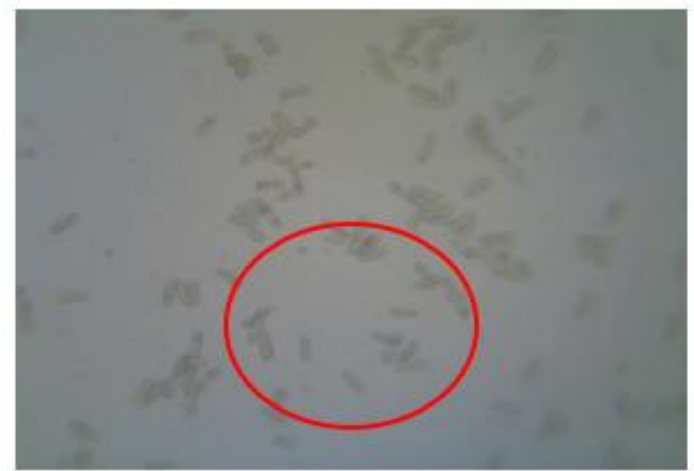

Gambar 18 Konidia Colletrotrichum sp. di bawah mikroskop dengan perbesaran 400x
Konidia pada L. theobromae hialin dan tidak bersekat, namun lama kelamaan konidia tersebut berwarna coklat dan bersekat. Sedangkan hifa patogen ini bersekat, hialin pada hifa muda, dan coklat pada hifa tua. Hal ini sesuai dengan Aisyah (2014) yang menjelaskan hasil pengamatan $L$. theobromae. Suhu optimum cendawan berkisar $25^{\circ} \mathrm{C}-30^{\circ} \mathrm{C}$ dan kelembabannya sekitar $90 \%$. Pencegahan patogen ini dapat menggunakan agen hayati seperti Trichoderma harzianum dan Gliocladium sp. (Octaviani et al. 2015).

\section{Gloeosporium spp.}

a. Gloeosporium sp. 1

Isolat dengan kode S17 1 didapatkan dari gejala hawar daun dapat dilihat pada Gambar 22 (a). Sedangka warna isolat yang didapatkan adalah berwarna putih dan permukaan miselium terlihat kasar berserat. (Gambar 22 (b). Hasil inokulasi menunjukkan bahwa isolat dengan kode s17 1 menghasilkan pesentase serangan yang paling tinggi yaitu $80 \%$ pada daun jabon merah yang dilukai dan $40 \%$ pada daun jabon merah yang tidak dilukai.
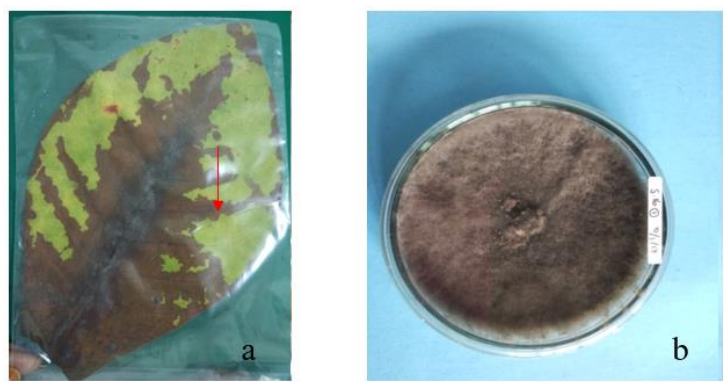

Gambar 19 (a) Gejala hawar daun dari L. theobroma (Skala 1: 10), Isolat L. theobromae (Skala 1: 5)

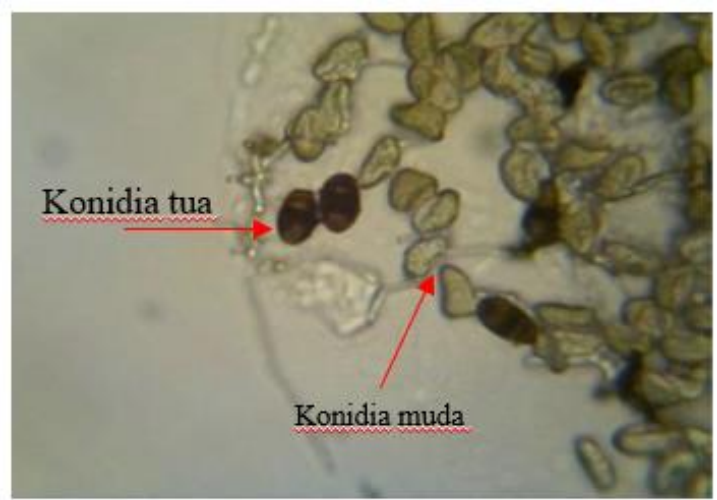

Gambar 20 Konidia L. theobromae di bawah mikroskop dengan pembesaran $400 \mathrm{x}$
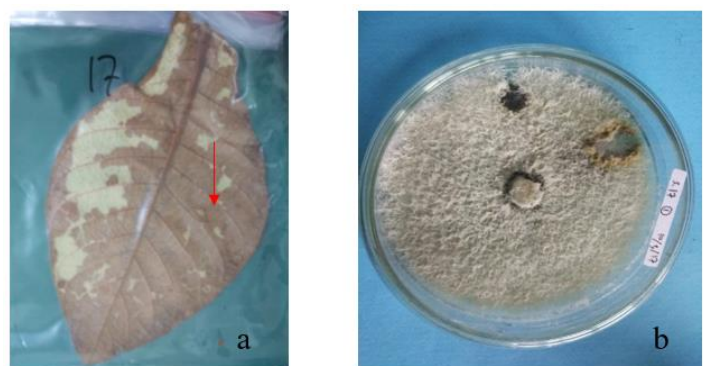

Gambar 21 (a) Gejala daun dari cendawan Gleosporium sp. 1, (b) Isolat Gleosporium sp. 1 
Setelah dilakukan identifikasi, isolat tersebut merupakan cendawan Gloeosporium sp. Anggraeni (2009) menyatakkan bahwa, salah satu patogen bercak daun pada tanaman hutan adalah Gloeosporium sp.. Sementara Indaryaniningsih (2016) menyatakkan bahwa, penyebab penyakit hawar daun pada tanaman hias drasena (Dracaena sp.) adalah Gloeosporium sp.. Dapat disimpulkan bahwa Gloeosporium sp. menyebabkan gejala yang berbeda pada tanaman yang berbeda.

Ciri-ciri makroskopis dari patogen ini yaitu memiliki hifa yang hialin dan bersepta (bersekat) (Gambar 24 (a)), juga memiliki konidia yang berbentuk basil dan tersebar banyak disekitar hifa (Gambar 24 (b)). Afriyeni et al. (2013), juga menyatakan bahwa patogen ini dapat menyebabkan pembusukan pada buah kakao. Suhu optimum cendawan berkisar $25^{\circ} \mathrm{C}-30^{\circ} \mathrm{C}$ dan kelembabannya sekitar $90 \%$. Cara pencegahan dan pengendalian serangan cendawan sama seperti cendawan lainnya, yaitu dengan melakukan sanitasi, menyemprotkan fungisida, maupun dengan penyebaran musuh alaminya.

\section{b. Gloeosporium sp. 2}

Isolat dengan kode S17 2 didapatkan dari gejala hawar daun dapat dilihat pada Gambar 25 (a). Sedangka warna isolat yang didapatkan adalah berwarna putih dan keabuan ditengah, permukaan lebih halus dari S17 1 (Gambar 25 (b). Hasil inokulasi menunjukkan bahwa isolat dengan kode s17 1 menghasilkan pesentase serangan sebesar $50 \%$ pada daun jabon merah yang dilukai dan $30 \%$ pada daun jabon merah yang tidak dilukai. Hasil tersebut merupakan hasil yang tertinggi dari 3 ulangan bibit jabon merah yang diinokulasi patogen dengan kode isolat S17 2.

Pengamatan mikroskopis kode isola S17 2 memiliki ciri-ciri yang sama dengan ciri-ciri mikroskopis kode isolat S17 2, sehingga cendawan ini juga merupakan Gloeosporium sp.
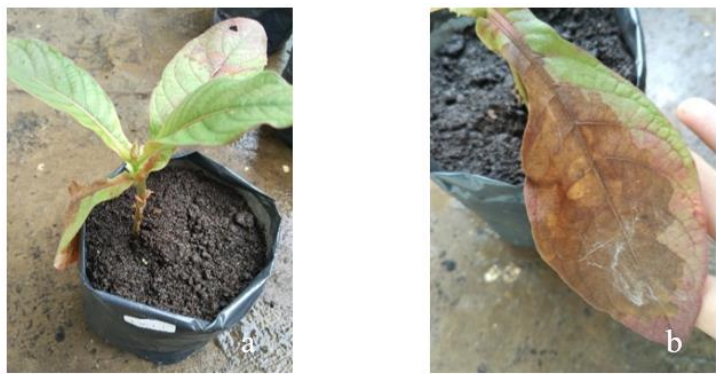

Gambar 22 (a) Bibit yang terserang Gloeosporium sp. 1 (Skala 1:5), (b) Gejala akibat cendawan Gloeosporium sp. (Skala 1:10)
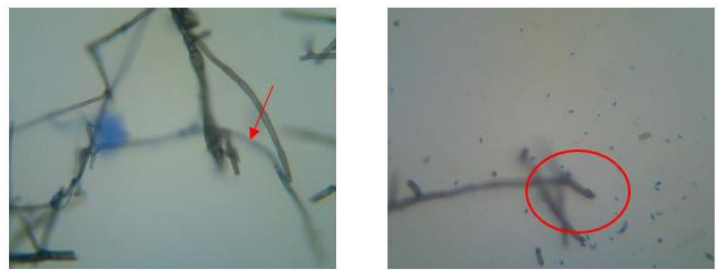

Gambar 23 (a) Hifa isolat Gloeosporium sp. 1 di bawah mikroskop dengan perbesaran 400x, (b) Konidia Gloeosporium sp. 1 di bawah mikroskop dengan perbesaran 400x

\section{SIMPULAN DAN SARAN}

\section{Simpulan}

Hasil identifikasi ditemukan sebanyak 8 jenis cendawan penyebab penyakit daun pada jabon merah sebanyak 2 cendawan ditemukan berasal dari gejala penyakit bercak daun yaitu Pestalotia sp. dan Rhizoctonia sp.. Sebanyak 6 cendawan ditemukan berasal dari gejala penyakit hawar daun yaitu $L$. theobromae, Fusarium sp., Colletrotrichum sp., Marssonia sp., Gloeosporium sp. 1, dan Gloeosporium sp. 2.

\section{Saran}

Cendawan-cendawan penyebab penyakit daun dapat berkembang di persemaian. Oleh karena itu, persemaian jabon merah perlu diperhatikan kondisi lingkungannya. Perlu adanya sanitasi pada persemaian jabon merah untuk mengantisipasi penyebaran cendawan. Pengamatan gejala penyakit di lapang juga perlu dilakukan untuk mengetahui cara penyebaran penyakit, keparahan penyakit, dan persentase serangannya.

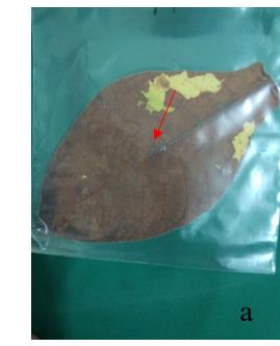

Gambar 24 (a) Gejala daun dari cendawan Gloeosporium sp. 2, (b) Isolat Gleosporium sp. 2
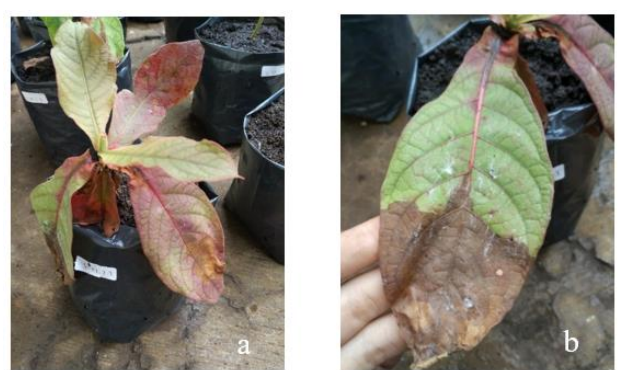

Gambar 25 (a) Bibit yang terserang Pestalotia sp. (Skala 1:5), (b) Gejala akibat cendawan Pestalotia sp (Skala 1:5)

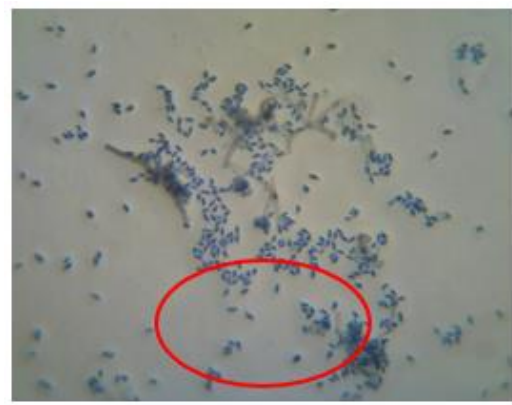

Gambar 26 Hifa dan konidia Gloeosporium sp. 2 di bawah mikroskop dengan perbesaran 400x 


\section{DAFTAR PUSTAKA}

Achmad, Hadi S, Haran S, Sa'id EG, Satiawiharja B, Kardin MK. 2012. Mekanisme serangan patogen lodoh pada semai pinus (Pinus merkusii). Journal of Tropical Silviculture Science and Technology. 03(1):57-64.

Agrios GN. 2005. Plant Pathology $5^{\text {th }}$ ed. New York (US): Elsevier Academic Pr.

Aisah AR. 2014. Identifikasi dan Patogenitas Cendawan Penyebab Primer Penyakit Mati Pucuk pada Bibit Jabon (Anthocephalus cadamba (Roxb.) Miq) [Tesis]. Bogor (ID): Institut Pertanian Bogor.

Barnett HL. 1965. Illustrated Genera of Imperfect Fungi. Mineapolis (US): Burges Publishing Company.

Departemen Kehutanan. 2006. Produksi Kayu Bulat Berdasarkan Sumber Produksi. Jakarta.

Halawane JE, Hanif NH, Kinho J. 2011. Prospek Pengembangan Jabon Merah merah (Anthocephalus macrophyllus (Roxb.) Havil), Solusi Kebutuhan Kayu Masa Depan. Manado: Badan Penelitian dan Pengembangan Kehutanan.

Herliyana EN, Achmad, Putra A. 2012. Pengaruh pupuk organik cair terhahadap pertumbuhan bibit jabon (Anthocephalus cadamba miq.) dan ketahanannya terhadap penyakit. Silvikutur Tropika. 03(03):168173.

Hidayah NH, Anggraeni I. 2015. Identifikasi penyebab penyakit bercak merah pada bibit jabon merah di persemaian permanen kima atas, Balai Penelitian Kehutanan Manado. Wasian. 2(2):73-78Hyde KD, Cai L, McKenzie EHC, Yang YL, Zhang JZ, Prihastuti H. 2009. Colletrotrichum: a catalogue of confusion. Fungal Diversity. 39:1-17.

Indaryaniningsih, Novalia. 2016. Identifikasi Penyakit Hawar Daun pada Tanaman Hias Drasena (Dracaena sp.) serta Uji Daya Hambatnya Menggunakan Cendawan Gliocladium sp., Aspergillus sp., dan Fusarium sp. secara In Vitro [Skripsi]. Malang (ID): Universitas Brawijaya.

Irawan A, Anggraeni I, Christia M. 2015. Identifikasi penyebab penyakit bercak daun pada bibit cempaka (Magnolia elegans (Blume.) H. Keng) dan teknik pengendaliannya. Wasian. 2(2):87-94.

Ismail AM. Cirvilleri G, Polizzi G, Crous PW, Groenewald JZ, Lombard L. 2012. Lasiodiplodia spesies associated with dieback disease of mango (Mangifera indica) in Egypt. Australasian Plant Pathol. 41: 649-660.

Kronstad JW. 2000. Fungal Pathology. Nederlands (NL) : Kluwer Academic Publisher.
Lee DH, Back CG, Win NK. 2011. Biological characterization of Marssonina coronaria associated with apple blotch disease. Mycobiology. 39(3):200-205

Manik FY, Herdiyeni Y, Herliyana EN. 2016. Leaf morphological feature extraction of digital image Anthocephalus cadamba. Telkomnika. 14(2):630637.

Mulyana D, Asmarahman C. 2011. 7 Jenis Kayu Penghasil Rupiah. Jakarta (ID): Penerbit PT Agromedia Pustaka.

Octaviani EA, Achmad, Herliyana EN. 2015. Potensi Trichoderma harzianum dan Gliocladium sp. sebagai agens hayati terhadap Botryodiplodia sp. penyebab penyakit mati pucuk pada jabon (Anthocephalus cadamba (Roxb.) Miq). Silvikultur Tropika. 06(1):27-32.

Rahayu S. 1999. Penyakit Tanaman Hutan di Indonesia. Yogyakarta (ID): Kanisius.

Rahayu D, Rahayu WP, Lioe HN, Herawati D, Broto W, Ambarwati S. 2015. Pengaruh suhu dan kelembaban terhadap pertumbuhan Fusarium verticillioides BIO 957 dan produksi Fumonisin B1. AGRITECH. 35(2):156-163

Semangun H. 1996. Pengantar Ilmu Penyaki Tumbuhan. Yogyakarta (ID): Gadjah Mada University.

Walker JC. 1975. Plant Pthology. New York (AS): Mc. Graw-Hill Book Company Inc.

Soenartiningsih, Akil M, Andayani NN. 2015. Cendawan tular tanah (Rhizoctonia solani) penyebab penyakit busuk pelepah pada tanaman jagung dan sorgum dengan komponen pengendaliannya. IPTEK Tanaman Pangan. 10(2):85-92.

Stević M, Pukš̉a P, Elezović I. 2010. Resistance of Venturia inaequalis to demethylation inhibiting (DMI) fungicides. Žemdirbyst $\dot{e}=$ Agriculture. 97(4):65-72.

Utami S, Anggraeni I, Sahwalita. 2008. Serangan penyakit daun pada jelutung darat (Dyera costulata Hook.) dan jelutung rawa (Dyera lowii Hook.) di Sumatera Selatan. Teko Hutan Tanaman $1(1): 45-52$.

Yamni K, Dohou A, Outcoumit AO, Touhami A, Douira. 2006. First report of Pestalotia subciticularis on Pyrus mamorensis in Moroco. Phytopathology Mediterranea (45):40-22.

Yunasfi. 2002. Faktor-Faktor yang Mempengaruhi Perkembangan Penyakit yang Disebabkan oleh Cendawan [Skripsi]. Medan (ID): USU Digital Library. 